\title{
The role of psychic distance stimuli on the East-West FDI location structure in the EU. Evidence from Spanish MNEs*
}

\author{
Alfredo Jiménez Palmero, Juan José Durán Herrera, Juan Manuel de la Fuente \\ Sabate *** $^{* *}$
}

Eastern Europe nowadays represents an important and attractive economic area for foreign direct investment. Determinants of investments have converged with those of other European countries. However, it has been argued that a differentiated East-West structure still exists in Europe. This study examines the existence of such a structure from the novel perspective of psychic distance stimuli, showing no evidence of its persistence. Moreover, the results provide evidence on the fundamental role played by different dimensions of psychic distance, especially in levels of industrial development and language, as obstacles to foreign direct investments. On the contrary, distance in education is positively associated with investments, reflecting an efficiency-seeking MNE approach.

Heutzutage ist Osteuropa ein wichtiger und attraktiver Wirtschaftsraum für ausländische Direktinvestitionen. Die Determinanten der Investitionen haben sich denen anderer europäischer Länder angenähert. Allerdings wurde angeführt, dass in Europa noch immer eine differenzierte Ost-West-Struktur vorhanden ist. Die vorliegende Studie untersucht die Existenz einer solchen Struktur aus der neuartigen Perspektive der psychischen Distanz-Stimuli, die keine Anzeichen für Beharrlichkeit zeigen. Darüber hinaus liefern die Ergebnisse Hinweise auf die fundamentale Rolle, welche die verschiedenen Dimensionen der psychischen Distanz spielen, vor allem in den Stufen der industriellen Entwicklung und der Sprache, als Hindernis für ausländische Direktinvestitionen. Die Kluft in der Bildung ist positiv mit Investitionen verbunden, was auf einen Effizienz-orientierten Ansatz schließen lässt.

Keywords: Psychic Distance, Multinational Enterprise, Direct Foreign Investment, Conditional Logit Model, Central and Eastern European Countries.

\footnotetext{
Manuscript received: 6.1.2012, accepted: 15.5 .2012 (1 revision)

** Alfredo Jiménez Palmero, Universidad de Burgos, Facultad de Ciencias Económicas y Empresariales. Main research interests: Impact of institutional aspects on the internationalization strategy of Multinational Enterprises and on entrepreneurship. Email: ajimenez@ubu.es

Juan José Durán Herrera, Autonomous University of Madrid. Main research interests: Impact of institutional aspects on the internationalization strategy of Multinational Enterprises and on entrepreneurship.

Juan Manuel de la Fuente Sabaté, University of Burgos. Main research interests: Impact of institutional aspects on the internationalization strategy of Multinational Enterprises and on entrepreneurship.
} 


\section{Introduction}

Central and Eastern European countries (CEEs ${ }^{1}$ ) have received much higher inward Foreign Direct Investment (FDI) than ever before, since the 1990s up to the beginning of the financial crisis towards the end of 2000. There is no doubt that the start and the success of their negotiations to join the European Union (EU) increased the attractiveness of these countries as possible host markets for Multinational Enterprises (MNEs) from a wide range of home countries. As an illustrative example of the pivotal role of the EU member status on inward FDI in the region, total accumulated FDI, which had stood at around 97,726 million dollars in the year 2000, rose to 229,734 million dollars in 2004, which represents an increase of $135 \%$. In this same period, the growth of accumulated direct investment in the world grew by only 53.87\%: in the developed economies by $62.7 \%$, and in Central and Latin America by $41.07 \%{ }^{2}$.

EU membership was a crucial determinant to attract FDI from European countries in which a large number of the MNEs had recently embarked on internationalization. A clear example is Spain, a country characterized by the significant internationalization process of its firms in the 1990s, but considered a "late investor" in the European context. The greater part of Spanish FDI is still channelled towards more traditional destinations in Western Europe and Latin America. However, Galan et al. (2007) and Jiménez (2011) point to Eastern Europe as one of the regions that has become increasingly relevant for Spanish MNEs in the last decade, along with the North of Africa and some Asian countries. Specifically, inward FDI received by the new members of the EU rose from $5.4 \%$ in 2003 and only $2.6 \%$ in 2004, to represent $25.9 \%$ of total Spanish FDI in the world, which is equivalent to a $626 \%$ increase over the preceding year $^{3}$. Poland, Czech Republic and Hungary were the main destinations of Spanish MNEs, and, despite telecommunications and banking accounting for the lion's share of the total value of investments, many relatively smaller MNEs from the manufacturing sector entered the region as well (2011a). In addition to geographic closeness, firms took advantage of the EU membership perspectives and subsequent member-state status, which translated into a common market and rules of the game that had greater similarity.

This increased attractiveness of the region as an FDI destination also entailed important growth in academic research and publications that analyzed the phenomenon. For instance, several papers underlined the crucial role of

\footnotetext{
${ }^{1}$ There is no official agreement on which countries should be included in the list of CEECs (Gomez-Barroso and Feijoo, 2010). In this paper, the term CEE is used to refer to the new member states that joined the European Union in 2004: Cyprus, Czech Republic, Estonia, Hungary, Latvia, Lithuania, Malta, Poland, Slovakia and Slovenia,

${ }^{2}$ Percentages prepared by the author on the basis of data taken from the UNCTAD World Investment Report 2005 Statistical Annex available at www.unctad.org (Data accessed 03/17/2011)

${ }^{3}$ Percentages prepared by the author on the basis of data taken from the DATAINVEX database of the Spanish Ministry of Industry, Tourism and Trade (Data accessed 03/29/2011)
} 
privatizations (Holland/Pain; 1998), protection of property rights (Smarzynska 2002), sector of origin (Resmini 2000), uncertainty (Pennings/Altomonte 2003), labour costs (Bellak et al. 2008), institutional quality (Bevan/Estrin 2004), taxes (Bellack et al. 2009), productivity and spillovers (Holland et al. 2000; Damijan et al. 2003; Peneder/Stehrer 2007) and even the possibility, finally rejected, of diverted investments from other European regions (Buch et al. 2003; Galego et al. 2004).

Interestingly, Disdier and Mayer (2004) highlight that there are still a persistent East-West structure in the location of French MNEs, despite the convergent trend of the determining factors that drive the decisions to set up in either Western or in Eastern Europe. Analyzing the different levels of institutional quality and political risk, Jiménez et al. (2011a) reached the same conclusion in the case of Spanish MNEs, demonstrating that both countries with a long tradition as investors and "late investors" distinguish this differentiated EastWest structure, which may constitute a great obstacle for the economic and social cohesion policies undertaken by the EU.

However, neither work takes into consideration one of the concepts that has attracted most attention in research on international business over the past few decades: psychic distance. Griffith et al. (2008) point to the role of cultural and institutional aspects as one of the most relevant lines of study in the field of international business. More precisely, psychic distance may be considered a concept that embraces and encompasses cultural distance (Dow/Karunaratna 2006). It forms part of the informal institutions that, together with the formal ones, determine the third pillar of a new paradigm in business strategy comprising the resource-based, the industrial-based and the institutional-based approaches (Peng et al. 2008).

Taking into account the increasing relevance of CEE countries as a region of destination for Spanish FDI, the impact of investment location in the cohesion policies with the EU and the need to analyze the role of informal institutions, the aim of this paper is to determine whether MNEs from Spain perceive this differentiated East-West structure between the new members and the other Western countries of the EU, when including the impact of psychic distance stimuli. In addition, we seek to differentiate the individual effects of each different dimension of psychic distance stimuli to which the managers of the MNEs are exposed.

The rest of the paper is structured in the following way: section 2 reviews the literature consecrated to the theoretical and empirical study of the concept of psychic distance and formulates the hypotheses. Section 3 describes the sample, the variables and models used in the empirical study. Section 4 presents and discusses the results and finally the main conclusions are drawn in Section 5. 


\section{Review of the literature and hypotheses}

\subsection{Review of the psychic distance literature}

Psychic and cultural distance have received a great deal of attention in the literature on international business over various decades, perhaps because of its attractiveness as a theoretical concept. Cho and Padmanabhan (2005:309) even point out that "almost... no international business study can be complete unless there is an explicit variable controlling for cultural distance". However, consensus over its definition is still a controversial matter (see Prime et al. 2009 for a review of numerous definitions given by various authors). For instance, O'Grady and Lane (1996), define psychic distance as "a firm's degree of uncertainty about a foreign market resulting from cultural differences and other business difficulties that present barriers to learning about the market and operating there". Håkanson and Ambos (2010) consider it as the subjectively perceived distance to a given foreign country, reflecting the perceiver's knowledge, familiarity and sense of understanding of it. This conceptualization of psychic distance is not only in line with the original one, but is also consistent with the semantic origins of the term (Håkanson/Ambos 2010).

The school of Uppsala Johanson/Wiedersheim-Paul 1975; Johanson/Vahlne 1977) popularized the concept of psychic distance, defining it as "the sum of factors preventing or disturbing the flow of information between firm and market. Examples are differences in language, culture, political systems, level of Johanson/Wiedersheim-Paul 1975:308). Despite numerous factors being included in the definition of the Swedish school, the scientific literature has centred its attention on the use of indices of cultural differences. Many studies frequently use those of Kogut and Singh (1988) which are based on the dimensions of national culture identified by Hofstede (1980), on the assumption that psychic distance can be approximated through a single composite measure of cultural distance. However, this methodology has been criticised for both theoretical and empirical reasons (Shenkar 2001; Kirkman et al. 2006; Håkanson/Ambos 2010). Sousa and Bradley (2006) and Dow and Karunaratna (2006) underline that cultural distance can only be considered as one of the components of the broader and more complex concept of psychic distance. Also, these authors were critical of adding the different dimensions in one single index, as it might, erroneously, lead one to think that all of them together are equally significant of the relations under analysis. Tung and Verbeke (2010:265) also point out that "cultural dimensions and measures do not fully capture psychic distance, which is really the key parameter affecting many managerial choices in an IB context". In fact, Dow and Karunaratna (2006) empirically underline the weaker predictive validity of Hofstede's scales compared to other more comprehensive measures of psychic distance. 
In addition, several authors have recently warned of the question of asymmetry when analyzing bidirectional flows. As highlighted by Shenkar (2001), the perceived distance from country A and country B is not necessarily equal the other way around. This issue may not be so very relevant in studies using a single focal country but it is worth mentioning and must be taken into account when more than one source country is under study (Brock et al. 2008; Ellis 2008; Håkanson/Ambos 2010)

These limitations seem to be the cause of the scant and ambiguous evidence found to date (Shenkar 2001; Tihanyi et al. 2005; Kirkman et al. 2006), and even of unexpected results such as the "psychic distance paradox" (O'Grady/Lane 1996; Evans/Mavondo 2002), which finds a negative relation between psychic closeness and business performance. If needed, Asymmetry must be taken into account in order to understand the complex phenomenon of psychic distance correctly. Also, additional factors must be included in the analysis, for instance, religion, education, industrial development and political systems, (Shenkar 2001; Evans/Mavondo 2002; Dow/Karunaratna 2006).

Finally, given the difficulty of measuring managerial perceptions immediately before a decision is taken and the causality problems of relying on ex-post perceptions (Dow/Karunaratna 2006; Dow/Ferencikova 2010), the greater part of empirical studies centre on macro-level factors known as 'stimuli' of psychic distance (Dow/Karunaratna 2006), although it is accepted that the managerial perception of psychic distance will depend on the psychic distance stimuli to which managers are exposed, moderated by their personal sensitivity towards such stimuli.

Despite the existence of some pitfalls related to the concept of psychic distance, several papers have shown its usefulness when analyzing a wide range of relevant topics. In fact, psychic distance stimuli have been used as explanatory variables for a great variety of phenomena, such as performance (O'Grady/Lane 1996; Dow/Ferencikova 2010), import-export relations (Prime et al. 2009), online internationalization (Yamin/Sinkovics 2006), the internationalization of small and medium knowledge-intensive enterprises (Ojala/Tyrvainen 2009), the behaviour of MNEs when entering foreign markets (Hosseini 2008) and especially the entry method (Dow/Larimo 2009; Dow/Ferencikova 2010). However, to the best of our knowledge, psychic distance stimuli have yet to be used as possible explanatory variables for the perception of a differentiated structure of a region in two areas.

\subsection{Formulation of the hypotheses}

As Hakason and Ambos (2010) state, "the general assumption in most (psychic distance) studies is that the more different a foreign environment is as compared to that of a firm's (or an individual's) country of origin, the more difficult it will be to collect, analyze and correctly interpret information about it, and the higher 
are therefore the uncertainties and difficulties - both expected and actual - of doing business there" (p. 195).

Following the recommendations of the above-mentioned authors, other factors beyond cultural distance, which has been revealed as a poor and unsatisfactory indicator, have to be included in order to analyze psychic distance stimuli (Dow/Karunaratna 2006; Dow/Ferencikova 2010). Thus, our paper specifically attempts to analyze the relation between the location of Spanish MNEs on the European continent and the six different dimensions of psychic distance that are proposed and justified by Dow and Karunaratna (2006) drawing on arguments from the Transaction Cost Theory (Williamson 1975, 1985). The six dimensions are: education, industrial development, language, degree of democracy, political ideology and religion (Dow 2011).

Building on this well-known theory, a higher psychic distance in any dimension between two countries will have an impact on risk and transaction costs, both real and perceived, which are increased by different barriers to learning about the host market and the higher possibility of mistakenly understanding its specific idiosyncrasies and environment. MNEs will have to incur higher search and information costs, bargaining costs, and policing and enforcement costs, in order to overcome this lower knowledge of the host markets and to protect themselves against opportunistic behaviour. In consequence, it is likely that they will reduce the intensity of trade and investment between the home and host countries.

Several authors have identified differences in education as a relevant factor in psychic distance, as the educational system obviously influences the way in which people communicate and understand information. Thus, and despite being occasionally used to control for factor costs differences between countries, large differences in educational levels may increase the MNE's uncertainty over a complete understanding of and communication with the various agents (suppliers, customers, employees, ...) that are active in the market in which it wishes to set up a subsidiary. The higher risk of misunderstanding and the efforts to try to overcome it translate into higher transaction costs for the MNE, thereby reducing the manager's perception of the attractiveness of that market (Johanson/Vahlne 1977; Cavusgil 1980, Dow/Karunaratna 2006). This argument allows the following hypothesis to be formulated:

H1: The greater the distance in education between the home country and the host country, the lower the probability that the MNE will have a subsidiary in that same host country.

Differences in levels of industrial development have also been frequently cited as an important factor in psychic distance (Dow/Karunaratna 2006). At an individual level, this may be due to the influence of people's former jobs, or even those of their parents on their way of communicating. Moreover, the level 
of economic development plays an important role at a collective level in communication, interaction and relations between firms. Business communication and interaction are likely to be very different in agrarian, industrialized or service-based economies (Dow/Karunaratna 2006). As in the case of education, significant differences in levels of industrial development between countries influence the way agents communicate and increase the risk of misunderstanding or misinterpretation. This, in turn, increases the uncertainty of transactions (or the costs to reduce that uncertainty), negatively affecting the decision to start or to maintain an investment. Thus, it may be established that:

H2: The greater the distance in industrial development between the home country and the host country, the lower the probability that the MNE will have a subsidiary in that same host country.

Differences in language between countries have also been identified as a relevant factor, as they increase transaction costs and risk (Dow/Karunaratna 2006). Despite the fact that some firms attempt to increase efficiency in communication through the adoption of English as a lingua franca, several organizational problems may arise especially when language proficiency is low (Welch et al. 2001). Mutual understanding is further complicated, because speakers will inevitably attach invisible and different meanings to the same words that stem from their own interpretive frames (Henderson-Kassis 2005). On the other hand, communication and understanding is easier and more efficient when agents are fluent in languages with a high degree of similarity. Thus, it is likely that the greater the distance between the home country language and the host country language, the higher the transaction costs that will reduce the probability of the MNE investing in the country, which leads to the formulation of the following hypothesis:

H3: The greater the distance in language between the home country and the host country, the lower the probability that the MNE will have a subsidiary in that same host country.

Most firms have to maintain an intense and bidirectional communication with government, as it plays a fundamental role in the regulation and formulation of relevant policies for the firm, such as competency or the protection of property rights. Hence, as underlined by Dow and Karunaratna (2006), large differences in the political systems between the home country and the host country will raise uncertainty in communication with authorities, increasing transaction costs. In addition, they also increase the chances of committing errors when forecasting how the local government will behave in the future, which policies will be implemented and even the reaction of competitors to these measures. Both effects are likely to reduce the MNEs' interest on potential host countries with very different perceived political systems as a possible FDI destination. Dow and Karunaratna (2006) recommend differentiating between the degree of 
democracy and the political ideology of the group in power, which they call the social system. Thus, the following two hypotheses are formulated:

H4a: The greater the distance in democracy between the home country and the host country, the lower the probability that the MNE will have a subsidiary in that same host country.

H4b: The greater the distance in political ideology between the home country and the host country, the lower the probability that the MNE will have a subsidiary in that same host country.

Finally, differences in religion as psychic distance stimuli are perhaps the least cited in the literature, as they are frequently included as a component of the cultural indices. However, the religious measures usually correlate only very slightly with those of culture and most studies just include a dummy variable (Dow/Karunaratna 2006). Religion may be considered one of the principal causes of conflict (Triandis 2000) and can also increase transaction costs and the risk of misinterpreting the market where the MNE wishes to run a business, as there is no doubt that religion has an influence on language, the way in which a society communicates and interacts and even what kind of behaviours are desirable or at least tolerable (Shenkar 2001; Dow/Karunaratna 2006). Therefore, the final hypothesis to be included affirms that:

H5: The greater the distance in religion between the home country and the host country, the lower the probability that the MNE will have a subsidiary in that same host country.

\section{Methodology}

\subsection{Sample and data collection}

The sample includes all Spanish MNEs of over 250 employees with FDI provided by the Spanish Foreign Trade Institute (ICEX), the www.oficinascomerciales.es website ${ }^{4}$ and other organizations affiliated to the ICEX at the end of 2007. This date was chosen due to the objective of this paper, which is to analyze the impact of psychic distance between two very relevant events: the adhesion of CEEs to the EU and the beginning of the financial crisis towards the end of 2000. We believe that given the hard negative consequences of this crisis, those MNEs most directly affected may have been forced to postpone or even abandon some investments until economies recover and reach a new expansion stage. In fact, and despite lying outside the scope of our paper, Elteto (2010) shows that as a consequence of the worldwide recession, most countries in the CEE region lost most of the attractiveness they had earned immediately after their accession to the EU.

\footnotetext{
${ }^{4}$ Data accessed 12/16/2008
} 
The location of each subsidiary was collected from the respective websites of each MNE. When such information was not available or there was no website, the firm was contacted by email or telephone. Only two companies refused to provide this information so we had to drop them from the sample. Finally, all those with at least one subsidiary in a Western European country member of the $\mathrm{EU}$ or in one of the CEE countries new member states in $2004^{5}$ were selected. In total, the sample was made of 659 locations of subsidiaries in Europe (129 in CEE countries) belonging to 160 Spanish MNEs.

\subsection{Dependent variable}

The dependent variable is the presence of the MNE's subsidiary in the relevant country. Thus, a dichotomous variable is defined that takes a value of 1 if the subsidiary is present in the country and 0 otherwise. Rather than the exact year of investment, the choice of this dependent variable is due to our wish to analyze the impact of psychic distance on the actual presence of firms in European markets, as well as to data availability issues. Following this procedure we can also, albeit imperfectly, take into account the dynamic relation of negotiations between MNE and local government that take place throughout the entire life of the investment, because a presence in the country represents the result of accumulated decisions taken by firms to maintain the investment over time and not to divest (Majocchi/Presutti 2009; Jiménez 2010). It thereby avoids drawing conclusions that are solely applicable to the specific moment at which the MNE entered the market, without taking into consideration the subsequent temporal evolution of the explanatory variable. Moreover, psychic distance stimuli usually undergoes very slow changes, almost from one generation to the next (Dow 2011), which is why although we acknowledge that it would be more appropriate to carry out a longitudinal analysis, it is unlikely that the results would be very different from a transversal one.

\subsection{Independent variables}

Bearing in mind the previously described methodological limitations of cultural indices and the fact that they do not provide data on all the countries that make up the sample, we used the scales proposed by Dow and Karunaratna (2006). These scales include six constructs for differences in education, industrial development, language, democracy, social system (political ideology of the group in power) and religion ${ }^{6}$.

\footnotetext{
${ }^{5}$ No investments in either Cyprus or in Malta are included in the sample, as no reliable data was found for the majority of the variables used in the study.

${ }^{6}$ Following the recommendation of the authors of these measures, the absolute values were used for the distances in the different constructs, except in the cases of language and religion.
} 
Each dimension is the single-factor solution of a principal component analysis for a set of instruments ${ }^{7}$. For education, United Nations data on differences in literacy and enrolment in second a third-level education rates between home and host country are included. For industrial development, ten different indicators are taken into account, namely differences in consumption of energy, vehicle ownership, employment in agriculture, number of telephones and televisions, etc. The language dimension is based on 5-point scales that focus on the differences between the dominant languages between any two countries and on the incidence of the investing country's major language within the host country and vice versa. For degree of democracy, differences in political rights, civil liberties and the POLCON and POLITY IV indices are included. The political ideology dimension is calculated on the basis of the ideological leanings of the chief executive's political party and the largest political party in the government. Finally, 5-point scales focused on the differences between the dominant religions of any two countries and the incidence of the investing country's dominant religion within the receiving country and vice versa are included in the religion dimension.

Given that no serious problems of multicollinearity exist, it was decided to carry out a simultaneous evaluation of the individual dimensions to distinguish which were significant and to what degree. In addition, the disaggregation of psychic distance measures increases the explanatory power of the models, as well as their specificity, precision and exactitude (Evans/Mavondo 2002) and counters the criticism voiced by some authors that refers to the risk of assuming that all the dimensions are equally significant when aggregated in a single index (Sousa/Bradley 2006; Dow/Karunaratna 2006).

The reasons for using these scales instead of others that are also of an exogenous nature, such as those proposed by Brewer (2007), is because, although both overlap in many aspects, those of Dow and Karunaratna (2006) cover a greater set of factors that are normally associated with psychic distance. In addition, those of Brewer (2007) are available for a smaller set of countries and are constructed from a perspective of a single country, in this case Australia (Dow/Ferencikova 2010).

Descriptive statistics of the independent and control variables are shown in Table 1.

See the seminal paper of Dow and Karunaratna (2006) for a more detailed description of the procedure to calculate the different psychic distance dimensions. 
Table 1: Descriptive statistics

\begin{tabular}{|c|c|c|c|c|c|}
\hline Variables & $\mathrm{N}$ & Mean & $\begin{array}{l}\text { Standard } \\
\text { Deviation }\end{array}$ & Minimum & Maximum \\
\hline Distance in education & 25476 & .783 & .302 & .404 & 1.692 \\
\hline $\begin{array}{l}\text { Distance in industrial } \\
\text { dev. }\end{array}$ & 25476 & .407 & .275 & .002 & .929 \\
\hline Distance in language & 25476 & .170 & .244 & -.258 & .526 \\
\hline Distance in democracy & 25476 & .108 & .0825 & .003 & .313 \\
\hline $\begin{array}{l}\text { Distance in social } \\
\text { system }\end{array}$ & 25476 & .322 & .225 & 0 & .667 \\
\hline Distance in religion & 25476 & -1.190 & .249 & -1.551 & -.531 \\
\hline FDI/GDP & 25476 & 4.072 & 5.473 & -11.284 & 20.752 \\
\hline Population & 25476 & 6.946 & .565 & 5.660 & 7.916 \\
\hline Unemployment & 25476 & .877 & .161 & .633 & 1.248 \\
\hline Age & 25476 & 1.661 & .293 & .778 & 2.220 \\
\hline ROE & 25476 & 24.806 & 141.661 & -20.279 & \#\#\#\#\#\#\# \\
\hline $\begin{array}{l}\text { Num. of previous } \\
\text { countries }\end{array}$ & 25476 & 22.301 & 18.957 & 1 & 89 \\
\hline \multicolumn{6}{|c|}{ Frequencies } \\
\hline Non diversified & 25476 & \multicolumn{2}{|c|}{$34,72 \%$} & & \\
\hline Related diversification & 25476 & \multicolumn{2}{|c|}{$47,24 \%$} & & \\
\hline $\begin{array}{l}\text { Unrelated } \\
\text { diversification }\end{array}$ & 25476 & \multicolumn{2}{|c|}{$18,05 \%$} & & \\
\hline Manufacturers & 25476 & \multicolumn{2}{|c|}{$42,14 \%$} & & \\
\hline Food & 25476 & \multicolumn{2}{|c|}{$6,65 \%$} & & \\
\hline Construction & 25476 & \multicolumn{2}{|c|}{$11,74 \%$} & & \\
\hline Regulated & 25476 & \multicolumn{2}{|c|}{$8,55 \%$} & & \\
\hline Financial & 25476 & \multicolumn{2}{|c|}{$6,91 \%$} & & \\
\hline Other sector & 25476 & \multicolumn{2}{|c|}{$24,01 \%$} & & \\
\hline Stock market & 25476 & \multicolumn{2}{|c|}{$43,35 \%$} & & \\
\hline
\end{tabular}


A first group of control variables includes characteristics related to host countries: the percentage of GDP represented by FDI as a measure of the degree of openness (abbreviated as FDI/GDP), the log of the population as a measure of its size and the unemployment rate. World Bank data sources were consulted for the variables on population and unemployment the data on inward flows of FDI were taken from UNCTAD (United Nations Conference on Trade and Development).

The second group of control variables covers characteristics that are specific to the MNEs: the logarithm of age, Return on Equity $\left(\mathrm{ROE}^{8}\right)$, the number of countries in which the MNE is present as a measure of its international experience, whether or not it is listed on the stock exchange market, the degree of diversification (distinguishing between no diversification, related diversification and unrelated diversification and maintaining the first as the omitted reference category to avoid problems of multicollinearity) and the industry to which it belongs (identifying six sectors: manufacturers, food, construction, regulated sectors -air transport, telecommunications, energy and water- financial and other sectors, which is left as the reference category).

Data was obtained from the SABI database and the annual accounts of the MNEs, with 2005 as the base year, to account for the time taken by FDI to react to its explanatory variables (Bevan/Estrin 2004). Unfortunately, it is not possible to include other variables such as the income or the number of employees in the MNE due to problems of multicollinearity with other variables. Nonetheless, this problem is mitigated by including the age of the MNE, which, at least partially, covers the effect of the size of the firm, as demonstrated by the correlation coefficients between these variables as well as by following the criterion when the sample was selected that the MNEs should employ at least 250 workers, which guaranteed that all of them were large companies.

These control variables specific to the MNEs are understood as attributes of the individuals, whereas the control variables specific to the countries are characteristic of possible choices of locations. The attributes of the individuals must be interacted with n-1 dummy variables for the possible choices in the Conditional Logit Model (CLM) as well as in the Nested Logit Model (NLM) (Statacorp, 2001). Given that the study aims to analyse the determinants of location in Eastern Europe and to compare them with Western Europe, the latter will be taken as the reference category, interacting the individual attributes with an Eastern Europe dummy variable.

\footnotetext{
${ }^{8}$ If ROA is included in the models instead of ROE, the results remain unchanged. Results available upon request from the authors.
} 


\subsection{Diagnosis of multicolinearity}

Table 2 shows the correlation coefficients of the independent variables and their Variance Inflation Factors (VIFs). Given that all of the values are below the limit of 10 that is recommended by Neter et al. (1985), Kennedy (1992) and Studenmund (1992) and only the variable 'age of the MNE' is found above the strictest limit of 5.3 proposed by Hair et al. (1999), it may be affirmed that there are no serious problems of multicollinearity. Despite this, and given that some authors claim that the different constructs of psychic distance usually have high correlation rates (Dow/Ferencikova 2010), independent regressions for each individual dimensions will also be tested. 


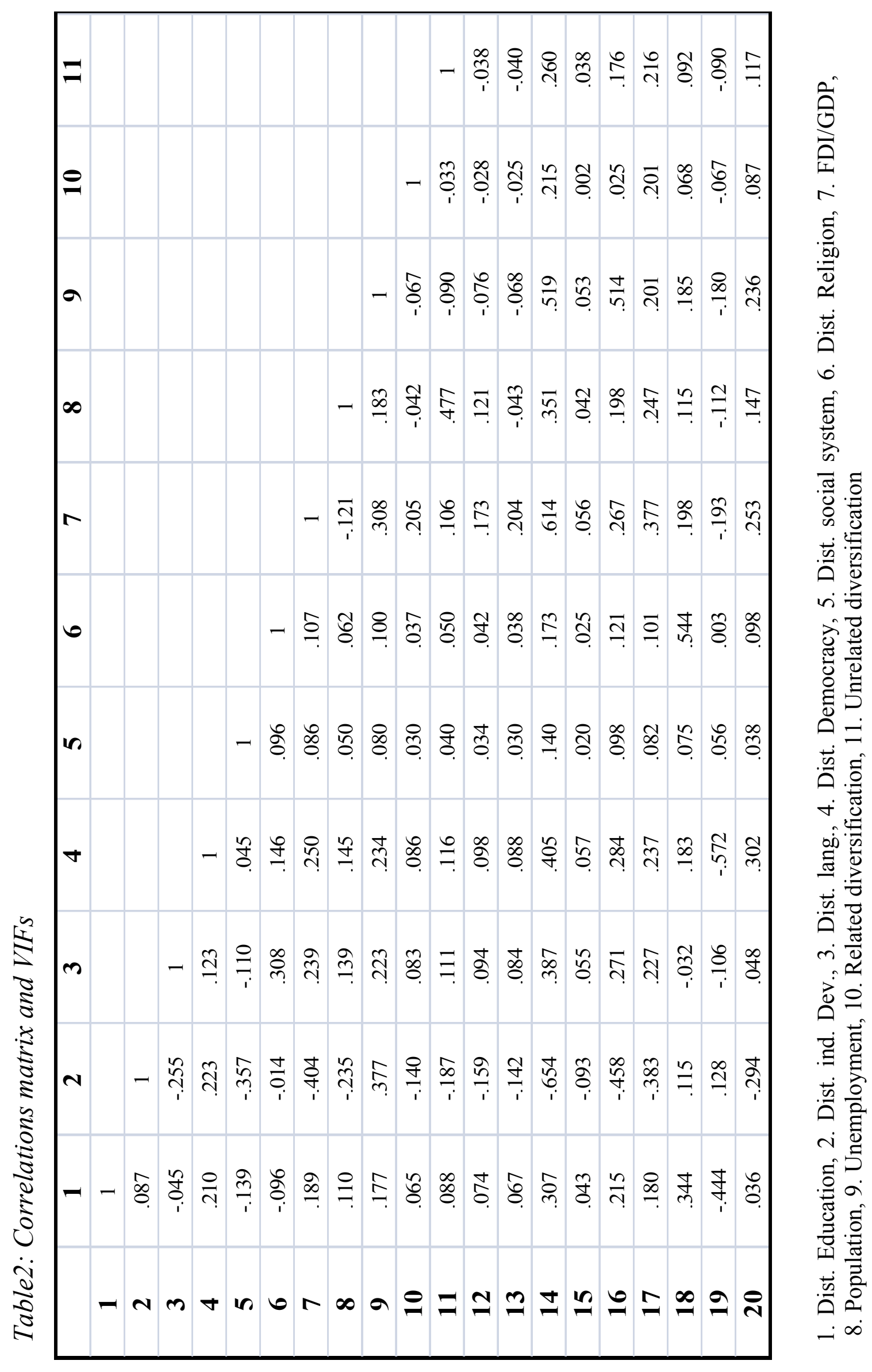




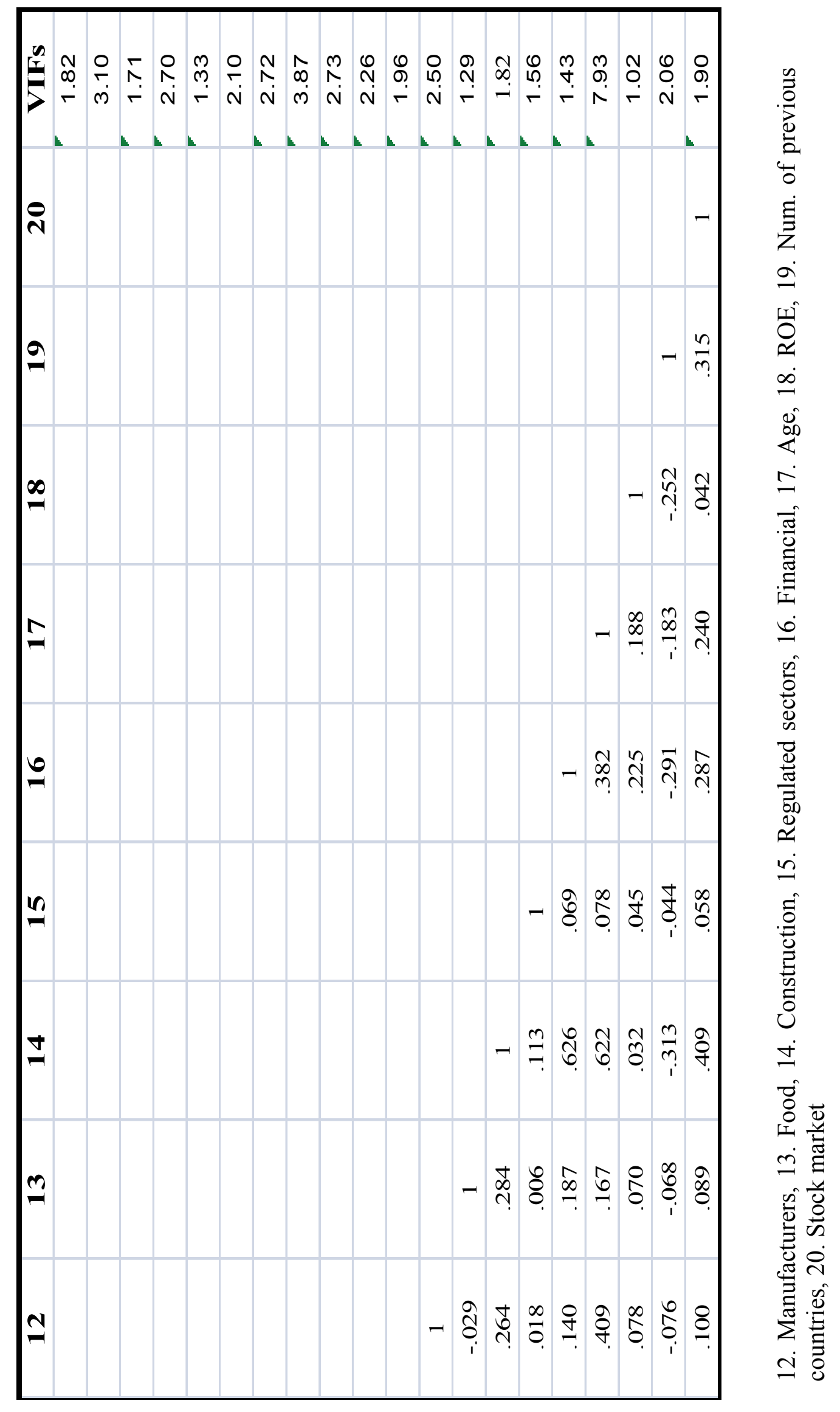




\subsection{Model}

The location of an MNE subsidiary may be understood as either a discrete choice between various alternatives represented by the different countries in which investments may be made, or as a structured two-stage decision in which, in the first step, the supranational geographic region is selected and then, in the second step, one of the countries within it.

In the first case, the Conditional Logit Model (CLM) proposed by McFadden (1984) with an endogenous qualitative variable is the appropriate statistical technique. This model estimates the coefficients by following the maximum likelihood procedure, maintaining the Independence of Irrelevant Alternatives (IIA). It means that the probability of selecting region $\mathrm{j}$ rather than alternative $\mathrm{i}$, given its conditional probability, will solely depend on the characteristics of the two alternatives and not on a third possible choice.

In the second case, the investors would take into account the attributes of all the countries situated in each region, in order to select one of them, before going on to select the particular country at the second level depending on the region selected in the first (Disdier/Mayer 2004). This decision structure in the form of a tree with two levels can be studied with the Nested Logit Model (NLM). Figure 1 provides a schematic view of the decision-making process for both models ${ }^{9}$.

A more detailed description of both models in relation to their mathematical developments, basic formulae and assumptions may be found in McFadden (1984), Cramer (1991), Maddala (1993), Mayer and Mucchielli (1999) and Disdier and Mayer (2004). 
Figure 1: Schematic diagram of the models

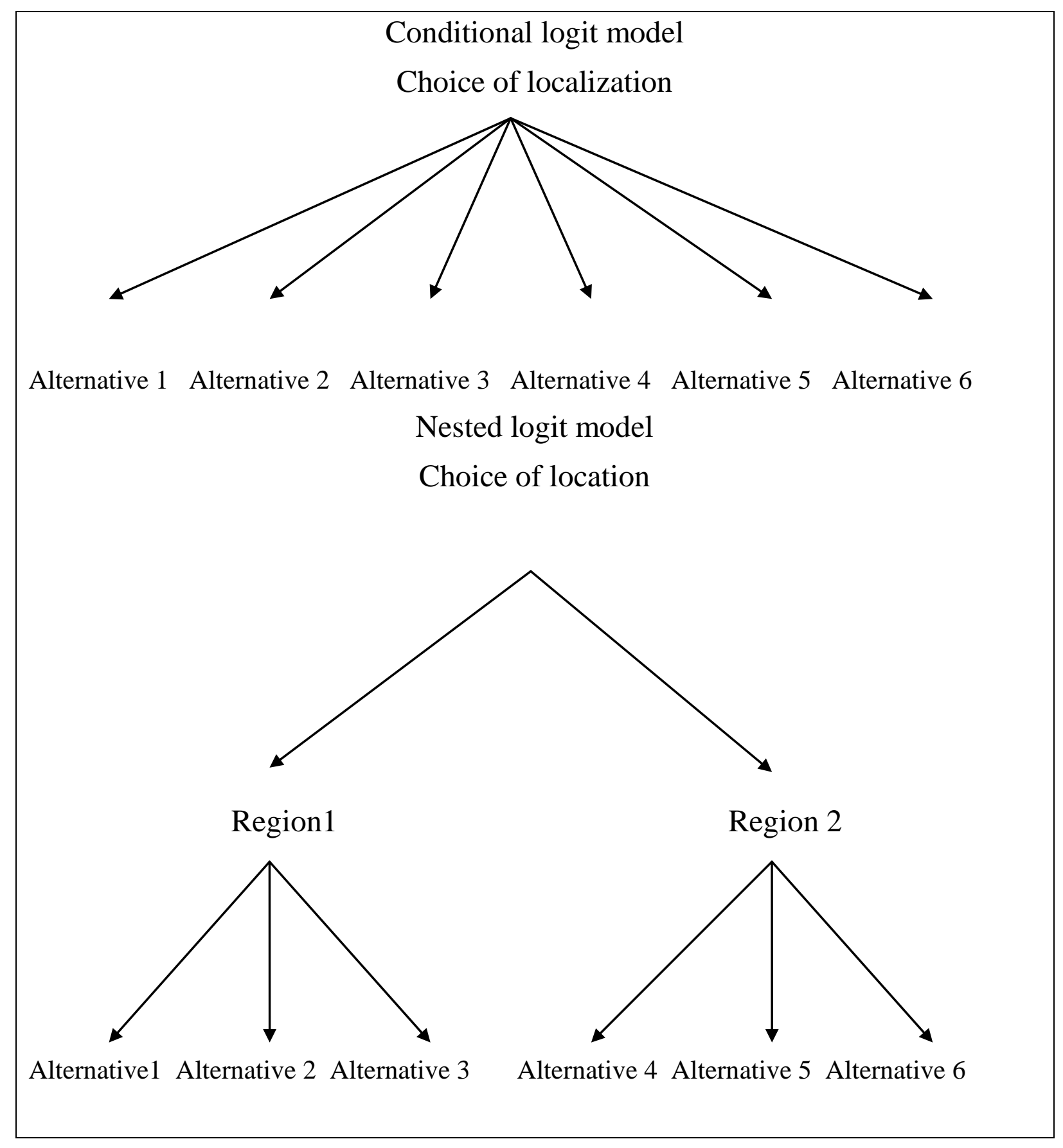

The Hausman and McFadden (1984) test and the inclusive value in the NLM are applied to confirm which of the two models is the most appropriate. In the first case, if the p-vale is low it will mean that the IIA assumption is not upheld, so it will be necessary to use the NLM. In the second, the value has to be between 0 and 1: the closer it is to one, the greater the perception of all countries as possible substitutes and only if it is closer to 0 will the choice of the region be relevant (Jiménez et al. 2011a). 


\section{Results}

The Hausman and MacFadden test demonstrated that the property of the Independence of Irrelevant Alternatives (IIA) is upheld and the inclusive value is indeed very close to 1 . Therefore the CLM is the most convenient method. This means that Spanish MNEs do not perceive a differentiated East-West structure with regard to psychic distance stimuli between the new and the longstanding members of the EU, or at least not as clearly as when analyzing the effects of agglomeration or the levels of institutional quality and political risk (Disdier/Mayer 2004; Jiménez et al. 2011a). It is likely that efforts to reduce the differences (in educational and industrial developments levels principally) between member states, either financed by European structural and cohesion funds or by the countries themselves, have facilitated a quicker assimilation of the new member states as possible alternative locations to traditional European markets.

Table 3 shows the results obtained when including all the dimensions of psychic distance in the same regression (Model 1) as well as in separate regressions (Models 2-7).

Table 3: Results of the conditional logit model (CLM)

\begin{tabular}{|c|c|c|c|c|c|c|c|}
\hline Variables & 1 & 2 & 3 & 4 & 5 & 6 & 7 \\
\hline \multirow[t]{2}{*}{$\begin{array}{l}\text { Distance in } \\
\text { education }\end{array}$} & $1.36 * * *$ & \multirow[t]{2}{*}{$\begin{array}{r}.80 * * * \\
(.201)\end{array}$} & & & & & \\
\hline & $-0,247$ & & & & & & \\
\hline \multirow{2}{*}{$\begin{array}{l}\text { Distance in } \\
\text { industrial dev. }\end{array}$} & $-1.06 * * *$ & & \multirow{2}{*}{$\begin{array}{l}-.96 * * * \\
(.244)\end{array}$} & & & & \\
\hline & $-0,324$ & & & & & & \\
\hline \multirow[t]{2}{*}{$\begin{array}{l}\text { Distance in } \\
\text { language }\end{array}$} & $-1.34 * * *$ & & & \multirow[t]{2}{*}{$\begin{array}{c}-1.35 * * * \\
(.169)\end{array}$} & & & \\
\hline & $-0,213$ & & & & & & \\
\hline \multirow[t]{2}{*}{$\begin{array}{l}\text { Distance in } \\
\text { democracy }\end{array}$} & $-0,96$ & & & & \multirow[t]{2}{*}{$\begin{array}{c}-3.82 * * * \\
(1.112)\end{array}$} & & \\
\hline & $-1,158$ & & & & & & \\
\hline \multirow[t]{2}{*}{$\begin{array}{l}\text { Distance in } \\
\text { social system }\end{array}$} & 0,047 & & & & & $\begin{array}{l}-.114 \\
(.185)\end{array}$ & \\
\hline & $-0,198$ & & & & & & \\
\hline
\end{tabular}




\begin{tabular}{|c|c|c|c|c|c|c|c|}
\hline \multirow{2}{*}{$\begin{array}{l}\text { Distance in } \\
\text { religion }\end{array}$} & 0,328 & & & & & & \multirow{2}{*}{$\begin{array}{l}-.521 * * \\
(.224)\end{array}$} \\
\hline & $-0,279$ & & & & & & \\
\hline \multirow[t]{2}{*}{ FDI/GDP } & $-0,01$ & \multirow{2}{*}{$\begin{array}{c}-.01 \\
(.011)\end{array}$} & 0,01 & \multirow{2}{*}{$\begin{array}{c}-.01 \\
(.011)\end{array}$} & 0,001 & \multirow{2}{*}{$\begin{array}{l}-.01 \\
(.011)\end{array}$} & 0,01 \\
\hline & $-0,017$ & & $-0,012$ & & $-0,011$ & & $-0,013$ \\
\hline \multirow[t]{2}{*}{ Population } & $1.28^{* * *}$ & \multirow{2}{*}{$\begin{array}{c}1.26^{* * * *} \\
(.093)\end{array}$} & \multirow{2}{*}{$\begin{array}{c}1.21^{* * *} \\
(.095)\end{array}$} & \multirow{2}{*}{$\begin{array}{c}1.16^{* * * *} \\
(.094)\end{array}$} & $.765^{* * *}$ & \multirow{2}{*}{$\begin{array}{c}1.20 * * * \\
(.098)\end{array}$} & \multirow{2}{*}{$\begin{array}{r}1.21 * * * \\
(.095)\end{array}$} \\
\hline & $-0,182$ & & & & $(.149)$ & & \\
\hline \multirow[t]{2}{*}{ Unemployment } & 0,21 & \multirow{2}{*}{$\begin{array}{c}.36 \\
(.306)\end{array}$} & 0,48 & \multirow{2}{*}{$\begin{array}{c}-.30 \\
(.343)\end{array}$} & \multirow{2}{*}{$\begin{array}{c}1.19 * * * \\
(.402)\end{array}$} & 0,32 & 0,21 \\
\hline & $-0,457$ & & $-0,314$ & & & $-0,314$ & $-0,321$ \\
\hline \multirow{2}{*}{$\begin{array}{l}\text { Related } \\
\text { diversication }\end{array}$} & 0,41 & \multirow{2}{*}{$\begin{array}{c}.41 * \\
(.250)\end{array}$} & 0,41 & \multirow{2}{*}{$\begin{array}{c}.44^{*} \\
(.251)\end{array}$} & \multirow{2}{*}{$\begin{array}{c}.42 \\
(.250)\end{array}$} & \multirow{2}{*}{$\begin{array}{c}.42 * \\
(.251)\end{array}$} & \multirow{2}{*}{$\begin{array}{c}.42 * \\
(.251)\end{array}$} \\
\hline & $-0,25$ & & $-0,25$ & & & & \\
\hline \multirow{2}{*}{$\begin{array}{l}\text { Unrelated } \\
\text { diversication }\end{array}$} & 0,12 & \multirow{2}{*}{$\begin{array}{c}.121 \\
(.354)\end{array}$} & 0,12 & 0,12 & 0,12 & 0,12 & 0,12 \\
\hline & $-0,354$ & & $-0,354$ & $-0,355$ & $-0,354$ & $-0,355$ & $-0,355$ \\
\hline \multirow[t]{2}{*}{ Manufacturers } & 0,38 & \multirow{2}{*}{$\begin{array}{c}.38 \\
(.292)\end{array}$} & 0,38 & 0,46 & 0,4 & 0,41 & 0,41 \\
\hline & $-0,292$ & & $-0,292$ & $-0,297$ & $-0,293$ & $-0,294$ & $-0,294$ \\
\hline \multirow[t]{2}{*}{ Food } & 0,32 & \multirow{2}{*}{$\begin{array}{c}.33 \\
(.448)\end{array}$} & \multirow{2}{*}{$\begin{array}{c}.32 \\
(.447)\end{array}$} & 0,4 & 0,34 & 0,356 & 0,36 \\
\hline & $-0,448$ & & & $-0,452$ & $-0,448$ & $-0,449$ & $-0,449$ \\
\hline \multirow[t]{2}{*}{ Construction } & 0,18 & \multirow{2}{*}{$\begin{array}{c}.20 \\
(.408)\end{array}$} & 0,17 & 0,29 & 0,2 & 0,23 & 0,22 \\
\hline & $-0,408$ & & $-0,408$ & $-0,41$ & $-0,408$ & $-0,408$ & $-0,408$ \\
\hline Regulated & $-0,14$ & \multirow[t]{2}{*}{$\begin{array}{c}-.13 \\
(.546)\end{array}$} & \multirow[t]{2}{*}{$\begin{array}{c}-.14 \\
(.546)\end{array}$} & $-0,09$ & \multirow[t]{2}{*}{$\begin{array}{c}-.13 \\
(.546)\end{array}$} & $\begin{array}{c}-.12 \\
(.547)\end{array}$ & $\begin{array}{c}-.12 \\
(.547)\end{array}$ \\
\hline Sectors & $-0,546$ & & & $-0,549$ & & & \\
\hline Financial & 0,18 & .17 & 0,18 & 0,08 & 0,15 & 0,14 & .14 \\
\hline & $-0,583$ & ) & $-0,582$ & $-0,586$ & $-0,583$ & $-0,584$ & $(.584)$ \\
\hline
\end{tabular}




\begin{tabular}{|c|c|c|c|c|c|c|c|}
\hline \multirow[t]{2}{*}{ Age } & $-.88 * * *$ & \multirow{2}{*}{$\begin{array}{r}-.84 * * * \\
(.199)\end{array}$} & \multirow{2}{*}{$\begin{array}{l}-.90 * * * \\
(.203)\end{array}$} & \multirow{2}{*}{$\begin{array}{c}-.46^{* *} \\
(.201)\end{array}$} & \multirow{2}{*}{$\begin{array}{c}-.78 * * * \\
(.198)\end{array}$} & \multirow{2}{*}{$\begin{array}{l}-.70 * * * \\
(.197)\end{array}$} & \multirow{2}{*}{$\begin{array}{r}-.70 * * * \\
(.1971)\end{array}$} \\
\hline & $-0,226$ & & & & & & \\
\hline \multirow[t]{2}{*}{ ROE } & 0,01 & 0,01 & 0,01 & 0,01 & 0,01 & 0,01 & 0,01 \\
\hline & $-0,007$ & $-0,007$ & $-0,007$ & $-0,007$ & $-0,007$ & $-0,007$ & $-0,007$ \\
\hline \multirow{2}{*}{$\begin{array}{l}\text { Num. of } \\
\text { previous } \\
\text { countries }\end{array}$} & 0,004 & 0,01 & 0,01 & 0,01 & 0,01 & 0,01 & 0,01 \\
\hline & $-0,005$ & $-0,005$ & $-0,005$ & $-0,005$ & $-0,005$ & $-0,005$ & $-0,005$ \\
\hline \multirow[t]{2}{*}{ Stock market } & $-0,01$ & \multirow{2}{*}{$\begin{array}{l}-.02 \\
.238)\end{array}$} & \multirow{2}{*}{$\begin{array}{l}-.01 \\
(.238)\end{array}$} & \multirow{2}{*}{$\begin{array}{c}-.08 \\
(.241)\end{array}$} & \multirow{2}{*}{$\begin{array}{c}-.03 \\
(.239)\end{array}$} & $-0,04$ & $-0,04$ \\
\hline & $-0,239$ & & & & & $-0,239$ & $-0,239$ \\
\hline $\begin{array}{l}\text { Num. of } \\
\text { observations }\end{array}$ & 14498 & 14498 & 14498 & 14498 & 14498 & 14498 & 14498 \\
\hline Log Likelihood & $-1806,9$ & $-1852,3$ & $-1852,5$ & $-1827,2$ & $-1853,9$ & $-1859,9$ & $-1857,4$ \\
\hline Pseudo R2 & 0,113 & 0,09 & 0,091 & 0,103 & 0,09 & 0,087 & 0,089 \\
\hline $\begin{array}{l}\text { Prob }>=\text { chi- } \\
\text { bar2 }\end{array}$ & 0 & 0 & 0 & 0 & 0 & 0 & 0 \\
\hline & & & & & & & \\
\hline & & & & $5 ; \quad * * *$ & .01 & & \\
\hline
\end{tabular}

In Model 1, both industrial distance and language are negative and significant as expected. This means that the greater the psychic distance, the lower the probability of investment in the country, which confirms hypotheses $\mathrm{H} 2$ and $\mathrm{H} 3$. However, distance in education is significant but with an unexpected positive sign, which rejects hypothesis H1. Differences in educational levels have also been used as a proxy for factor cost differences in the FDI literature. Therefore, a possible explanation for this result begins with the motivation behind the investments, assuming that lower levels of education imply lower salary levels. Several Spanish MNEs are characterized by an efficiency-seeking approach in this region (Jiménez et al. 2011b), which places a positive value on those locations in which they can minimize their salary costs. Thus, MNEs that plan the delocalization of activities with low qualification requirements might attempt to maximize the reduction in salary costs by investing in those countries 
in which the psychic distance in education is greater, although not so great that the workforce is unable to perform the tasks associated with the activity undergoing delocalization.

Further investigating this result, it was observed that all the distances in education were not only positive with the countries within the sample, but also with all the countries in the world for which the index has been calculated. According to the data used to calculate this variable -obtained through a principal components analysis of three different scales (Dow 2011)-, Spain is ranked in thirty-third position for illiteracy rates, but holds first and third position, respectively, for participation in secondary and tertiary education; a fact which appears unjustifiable even to the author of the psychic distance measures. Therefore the models were estimated again, in order to confirm that the results were not biased by a data-collection error. This time the variable for distance in education only used data on the literacy rate, provided by the author of the psychic distance indices. However, the results of both the CLM and the NLM, including all the dimensions of psychic distance, as well as the results of the models which only included the new variable for distance in education, once again confirmed the same result ${ }^{10}$. This empirical evidence reinforces the explanation that the positive relation between psychic distance in education and FDI is due to the efficiency-seeking approach of Spanish MNEs in this region, which are positively attracted by lower salary costs in those countries with lower scores for educational variables.

This empirical result obtained upholds and justifies the warning over the erroneous assumption identified by Tung and Verbeke (2010) that a higher distance systematically engenders negative outcomes, which many researchers have adopted. Distance can be viewed from a different perspective, not as a barrier or a challenge, but as an opportunity for arbitrage, complementarity or creative diversity (Ghemawat 2001, 2003; Shenkar et al. 2008; Zaheer et al. 2012). Positive outcomes might occur when a more positive or neutral reception is given by nationals to individuals from culturally distant countries in what is called "inverse resonance" (Carr et al. 2001), where distance can help firms to develop new capabilities and to access talent that is unavailable to them in closer countries and new knowledge and learning sources (Nachum et al. 2008) or, as in this case, where the investment motivation places a sharper focus on advantages derived from a greater positive distance, such as reduced salaries or input prices.

With regard to the control variables, the population of the host country is positive and significant as expected. Besides, the age of the MNE is also significant but negative. This result is due to the relatively recent creation of some of the Spanish MNEs with a greater international presence, in comparison

10 Results available upon request from the authors. 
with others of much greater age but with hardly any foreign locations (Jiménez 2010).

Models 2 to 7, each of which includes one single dimension of psychic distance, replicate Model 1. As well as confirming the earlier results, these models show a negative and significant coefficient of the distances in democracy and religion, providing evidence that confirms hypotheses $\mathrm{H} 4 \mathrm{a}$ and $\mathrm{H} 5$, although only partially as they were not significant in Model 1. Nevertheless, it is neither possible to validate nor to reject hypothesis $\mathrm{H} 4 \mathrm{~b}$, as the distance in social systems was not significant in either model. Moreover, the population and the age of the MNE are once again significant with the same sign, but, in addition, related diversification (Models 2, 4, 5 and 7) and unemployment (Model 5) are also positive and significant.

As further evidence of robustness, Table 4 also shows the results obtained from the NLM. They show no changes with respect to the independent variables: the negative and significant coefficients of the distances in industrial development and in language confirm hypotheses $\mathrm{H} 2$ and $\mathrm{H} 3$, and the positive and significant sign of distance in education rejects $\mathrm{H} 1$, both in the global and in the individual models. Equally, partial evidence is shown on hypotheses H4a and H5 as the distances in democracy and religion are negative and significant in their corresponding models in which they are individually included. Finally, it is not possible to comment on hypothesis $\mathrm{H} 4 \mathrm{~b}$, as the distance in social systems was not significant in either model.

Table 4: Results of the nested logit model (NLM

\begin{tabular}{|c|c|c|c|c|c|c|c|}
\hline Variables & 1 & 2 & 3 & 4 & 5 & 6 & 7 \\
\hline $\begin{array}{l}\text { Distance in } \\
\text { education }\end{array}$ & $\begin{array}{c}1.54 * * * \\
(.261)\end{array}$ & $\begin{array}{l}.86^{* * * *} \\
(.202)\end{array}$ & & & & & \\
\hline $\begin{array}{l}\text { Distance in } \\
\text { industrial } \\
\text { dev. }\end{array}$ & $\begin{array}{c}-1.38 * * * \\
(.345)\end{array}$ & & $\begin{array}{c}-1.07 * * * \\
(.246)\end{array}$ & & & & \\
\hline $\begin{array}{l}\text { Distance in } \\
\text { language }\end{array}$ & $\begin{array}{c}-1.19 * * * \\
(.217)\end{array}$ & & & $\begin{array}{c}-1.32 * * * \\
(.169)\end{array}$ & & & \\
\hline $\begin{array}{l}\text { Distance in } \\
\text { democracy }\end{array}$ & $\begin{array}{c}-.90 \\
(1.18)\end{array}$ & & & & $\begin{array}{c}-4.06 * * * \\
(1.13)\end{array}$ & & \\
\hline \multirow{2}{*}{$\begin{array}{l}\text { Distance in } \\
\text { social } \\
\text { systems }\end{array}$} & \multirow{2}{*}{$\begin{array}{l}.030 \\
(.197)\end{array}$} & & & & & $-0,107$ & \\
\hline & & & & & & $-0,185$ & \\
\hline
\end{tabular}




\begin{tabular}{|c|c|c|c|c|c|c|c|}
\hline $\begin{array}{l}\text { Distance in } \\
\text { religion }\end{array}$ & $\begin{array}{c}.255 \\
(.279)\end{array}$ & & & & & & $\begin{array}{l}-.52 * * \\
(.223)\end{array}$ \\
\hline \multirow[t]{2}{*}{ FDI/GDP } & \multirow{2}{*}{$\begin{array}{c}.007 \\
(.017)\end{array}$} & \multirow{2}{*}{$\begin{array}{l}-.012 \\
(.011)\end{array}$} & \multirow{2}{*}{$\begin{array}{l}.025^{*} \\
(.012)\end{array}$} & \multirow{2}{*}{$\begin{array}{l}-.012 \\
(.011)\end{array}$} & 0,003 & \multirow{2}{*}{$\begin{array}{l}-.004 \\
(.011)\end{array}$} & 0,01 \\
\hline & & & & & $-0,011$ & & $-0,013$ \\
\hline Population & $\begin{array}{r}1.30 * * \\
(.185)\end{array}$ & $\begin{array}{c}1.25 * * * \\
(.093)\end{array}$ & $\begin{array}{c}1.19 * * * \\
(.095)\end{array}$ & $\begin{array}{c}1.14 * * * \\
(.094)\end{array}$ & $\begin{array}{l}.71 * * * \\
(.149)\end{array}$ & $\begin{array}{c}1.17 * * * \\
(.098)\end{array}$ & $\begin{array}{c}1.18^{* * * *} \\
(.095)\end{array}$ \\
\hline \multirow{2}{*}{$\begin{array}{l}\text { Unemploym } \\
\text { ent }\end{array}$} & 0,483 & \multirow{2}{*}{$\begin{array}{c}.476 \\
(.309)\end{array}$} & \multirow{2}{*}{$\begin{array}{l}.615^{* *} \\
(.318)\end{array}$} & \multirow{2}{*}{$\begin{array}{l}-.206 \\
(.346)\end{array}$} & \multirow{2}{*}{$\begin{array}{c}1.34 * * * \\
(.406)\end{array}$} & 0,415 & 0,311 \\
\hline & $-0,463$ & & & & & $-0,317$ & $-0,324$ \\
\hline $\begin{array}{l}\text { Related } \\
\text { diversificati } \\
\text { on }\end{array}$ & $\begin{array}{l}.51 * * \\
(.258)\end{array}$ & $\begin{array}{l}.51 * * \\
(.258)\end{array}$ & $\begin{array}{l}.51 * * \\
(.258)\end{array}$ & $\begin{array}{l}.51 * * \\
(.258)\end{array}$ & $\begin{array}{l}.51 * * \\
(.258)\end{array}$ & $\begin{array}{l}.51 * * \\
(.258)\end{array}$ & $\begin{array}{l}.51^{* *} \\
(.258)\end{array}$ \\
\hline \multirow{2}{*}{$\begin{array}{l}\text { Unrelated } \\
\text { diversificati } \\
\text { on }\end{array}$} & \multirow{2}{*}{$\begin{array}{c}.136 \\
(.358)\end{array}$} & \multirow{2}{*}{$\begin{array}{c}.136 \\
(.358)\end{array}$} & \multirow{2}{*}{$\begin{array}{c}.136 \\
(.358)\end{array}$} & 0,136 & \multirow{2}{*}{$\begin{array}{c}.136 \\
(.358)\end{array}$} & \multirow{2}{*}{$\begin{array}{c}.135 \\
(.358)\end{array}$} & \multirow{2}{*}{$\begin{array}{l}.136 \\
(.358)\end{array}$} \\
\hline & & & & $-0,358$ & & & \\
\hline $\begin{array}{l}\text { Manufac- } \\
\text { turers }\end{array}$ & $\begin{array}{l}.64 * * \\
(.323)\end{array}$ & $\begin{array}{l}.64 * * \\
(.323)\end{array}$ & $\begin{array}{l}.64 * * \\
(.323)\end{array}$ & $\begin{array}{l}.64 * * \\
(.323)\end{array}$ & $\begin{array}{l}.64 * * \\
(.323)\end{array}$ & $\begin{array}{l}.64 * * \\
(.323)\end{array}$ & $\begin{array}{l}.64 * * \\
(.323)\end{array}$ \\
\hline \multirow[t]{2}{*}{ Food } & \multirow{2}{*}{$\begin{array}{c}.578 \\
(.473)\end{array}$} & \multirow{2}{*}{$\begin{array}{c}.58 \\
(.473)\end{array}$} & \multirow{2}{*}{$\begin{array}{c}.578 \\
(.473)\end{array}$} & \multirow{2}{*}{$\begin{array}{c}.58 \\
(.473)\end{array}$} & 0,58 & 0,58 & 0,58 \\
\hline & & & & & $-0,473$ & $-0,473$ & $-0,473$ \\
\hline \multirow{2}{*}{$\begin{array}{l}\text { Con- } \\
\text { struction }\end{array}$} & 0,51 & 0,51 & 0,51 & 0,51 & 0,51 & 0,51 & 0,51 \\
\hline & $-0,432$ & $-0,432$ & $-0,432$ & $-0,432$ & $-0,432$ & $-0,432$ & $-0,432$ \\
\hline Regulated & \multirow{2}{*}{$\begin{array}{c}-.01 \\
(.564)\end{array}$} & \multirow{2}{*}{$\begin{array}{l}-.01 \\
(.564)\end{array}$} & \multirow{2}{*}{$\begin{array}{l}-.01 \\
(.564)\end{array}$} & \multirow{2}{*}{$\begin{array}{l}-.01 \\
(.564)\end{array}$} & \multirow{2}{*}{$\begin{array}{l}-.01 \\
(.564)\end{array}$} & \multirow{2}{*}{$\begin{array}{c}-.01 \\
(.564)\end{array}$} & $-0,01$ \\
\hline Sectors & & & & & & & $-0,564$ \\
\hline Financial & $\begin{array}{c}-.09 \\
(.602)\end{array}$ & $\begin{array}{l}-.09 \\
(.602)\end{array}$ & $\begin{array}{l}-.09 \\
(.602)\end{array}$ & $\begin{array}{l}-.09 \\
(.602)\end{array}$ & $\begin{array}{l}-.09 \\
(.602)\end{array}$ & $\begin{array}{l}-.09 \\
(.602)\end{array}$ & $\begin{array}{l}-.09 \\
(.602)\end{array}$ \\
\hline Age & $\begin{array}{c}.39 \\
(.436)\end{array}$ & $\begin{array}{l}.39 \\
(.436)\end{array}$ & $\begin{array}{c}.39 \\
(.436)\end{array}$ & $\begin{array}{c}.39 \\
(.436)\end{array}$ & $\begin{array}{c}.39 \\
(.436)\end{array}$ & $\begin{array}{c}.39 \\
(.436)\end{array}$ & $\begin{array}{c}.39 \\
(.436)\end{array}$ \\
\hline ROE & $\begin{array}{c}.01^{*} \\
(.007)\end{array}$ & $\begin{array}{l}.01 * \\
(.007)\end{array}$ & $\begin{array}{l}.01 * \\
(.007)\end{array}$ & $\begin{array}{l}.01 * \\
(.007)\end{array}$ & $\begin{array}{c}.01 * \\
(.007)\end{array}$ & $\begin{array}{c}.01 * \\
(.007)\end{array}$ & $\begin{array}{l}.01 * \\
(.007)\end{array}$ \\
\hline
\end{tabular}




\begin{tabular}{|l|c|c|c|c|c|c|c|}
\hline $\begin{array}{l}\text { Num. of } \\
\text { previous } \\
\text { countries }\end{array}$ & $\begin{array}{l}.01 * * \\
(.006)\end{array}$ & $\begin{array}{c}.01 * * \\
(.006)\end{array}$ & $\begin{array}{c}.01 * * \\
(.006)\end{array}$ & $\begin{array}{c}.01 * * \\
(.006)\end{array}$ & $\begin{array}{c}.01 * * \\
(.006)\end{array}$ & $\begin{array}{c}.01 * * \\
(.006)\end{array}$ & $\begin{array}{c}.01 * * \\
(.006)\end{array}$ \\
\hline $\begin{array}{l}\text { Stock } \\
\text { market }\end{array}$ & -.24 & -.24 & $\begin{array}{c}-.24 \\
. .258)\end{array}$ & $\begin{array}{c}-.24 \\
(.258)\end{array}$ & $\begin{array}{c}-.24 \\
(.258)\end{array}$ & $\begin{array}{c}-.24 \\
(.258)\end{array}$ & $\begin{array}{c}.24 \\
(.258)\end{array}$ \\
\hline $\begin{array}{l}(.258) \\
\text { observations }\end{array}$ & 14498 & 14498 & 14498 & 14498 & 14498 & 14498 & 14498 \\
\hline $\begin{array}{l}\text { Log } \\
\text { Likelihood }\end{array}$ & $-1800,7$ & -1847 & $-1846,6$ & $-1824,7$ & $-1849,1$ & $-1855,8$ & $-1853,2$ \\
\hline Pseudo R2 & 0,9967 & 0,6778 & 0,3923 & 0,7501 & $-1,379$ & 0,1454 & 0,269 \\
\hline $\begin{array}{l}\text { Prob>=chi- } \\
\text { bar2 }\end{array}$ & 0 & 0 & 0 & 0 & 0 & 0 & 0 \\
\hline
\end{tabular}

\section{Conclusions}

This study has analyzed the impact of psychic distance stimuli on the location strategy in the European continent of MNEs from a "late investor" country, Spain. It has also tested whether in this regard a differentiated East-West structure exists for the factors that determine the location of FDIs, as demonstrated by Disdier and Mayer (2004) and Jiménez et al. (2011a), when analyzing the effects of agglomeration or levels of institutional quality and political risk.

To do so, and after rejecting other alternatives such as the cultural indices of Hofstede (1980) and Kogut and Singh (1988) due to their limitations, it was decided to use the indices prepared by Dow and Karunaratna (2006), which cover the distances between countries in six different areas: education, industrial development, language, democracy, social system and religion.

When the impact of psychic distance stimuli are taken into account, the results show that Spanish MNEs do not perceive such a differentiated structure between the new members of the EU from Central and Eastern Europe and the Western members. Given the emphasis on the need to increase cohesion and reduce differences between countries within the EU, which both states and European institutions have traditionally shared, we believe that this is a relevant contribution on FDI in the CEE region. Their efforts seem to have allowed a 
quicker and easier assimilation of the new member states as possible alternative locations to traditional European markets.

However, and despite not having found a differentiated East-West structure in relation to the psychic distance stimuli, our results also contribute to the market entry literature, by showing empirical evidence of the significant impact of several of these stimuli in the location strategy of Spanish MNEs in Europe. In particular, distances in levels of industrial development and language have been shown to have a negative relationship with Spanish FDI, as they increase transaction costs and constitute an obstacle to the attraction of investments. Distances in democracy and religion also have a negative effect, although in this case in a less pronounced way.

On the contrary, distance in education turned out to be significantly and positively associated with the likelihood of Spanish MNEs being present in the country. This result contributes to the psychic distance literature by offering empirical evidence of the fact that, as previously stated by several authors, greater distances do not systematically engender negative outcomes for the firm but, on the contrary, can sometimes be considered an opportunity (Ghemawat 2001, 2003; Shenkar et al. 2008; Tung/Verbeke 2010; Zaheer et al. 2012). The efficiency-seeking approach that many Spanish companies follow in this region, may propel them to search for lower input costs available in countries with lower scores and, therefore, at a greater distance in education from Spain.

Performing individual analyses of the different dimensions, rather than jointly in a single index, entails some advantages that deserve to be highlighted. By doing so, in addition to increasing the specificity, precision and exactitude of the results (Evans/Mavondo 2002), our results help managers in charge of the location strategy by providing more disaggregated information on the strategies followed by other MNEs and by distinguishing which dimensions are truly significant. Thus, some managerial actions may be considered in the light of our results, when psychic distance leads to high transaction costs. For instance, MNEs can exercise the implicit real option associated with FDI decisions (Rivoli/Salorio 1996; Li/Rugman 2007) and cancel or postpone the investment until the company becomes more familiar with the host market, or reconsidering the mode of entry if necessary. In addition, managers can achieve benefits for the company from a higher distance in a specific psychic distance dimension (education) by taking advantage of the lower input prices, especially when the activities that are the subject of delocalization do not require high-level qualification requirements. This paper also helps policy-makers in the host country who wish to increase inward flows of FDI, by enabling them to put policies into practice that minimize the effect of psychic distance in the relevant dimension, depending on the investor countries that they might wish to attract. In particular, our results show that higher distances in levels of industrial development and language and, to a lesser extent, democracy and religion have a 
negative impact on FDI. Therefore, in order to increase inward flows, countries will need to reduce the gap with the investor countries and, more importantly, ensure that this reduction effectively perceived. Furthermore, the results highlight the relevance of taking into consideration the motivation of the FDI projects undertaken in the country as a key variable for a successful policy implementation.

This study is subject to some limitations. It is important that theories are confirmed in a wide range of environments (Dow/Ferencikova 2010). Hence, an additional contribution of the present study lies in the analysis of a "late investor" country, which is the case of Spain, especially since the scientific literature has shown less interest in these types of investor countries in comparison with other developed economies. However, the fact that the sample includes MNEs exclusively from one single country means that the extrapolation of the results to other economies should be treated with caution. In addition, and despite relying on data and variables frequently used by researchers, we have to acknowledge the possibility of methodological differences between the data sources (World Bank, UNCTAD, Dow/Karunaratna 2006), as well as the omitted effect of personal characteristics of the top management due to data unavailability.

Finally, only the psychic distance stimuli based on exogenous scales and their impact on investment locations have been studied, without researching and incorporating the effect of the real perceptions of the managers. It is precisely the study of the relation between both variables, despite the difficulty of obtaining reliable measures, which constitutes one of the most important lines of future research that might widen our knowledge of the various decisions of MNEs, in which these variables play a relevant role.

\section{Acknowledgements}

The authors would like to thank the JEEMS editor, two anonymous reviewers, Douglas Dow, Anne-Celia Disdier, Juan Bautista Delgado and attendants to the 2011 AIB Annual Meeting and Euroconference 2001 for their valuable and helpful comments and suggestions. The first author also is grateful to Fundación Banco Herrero for financial support.

\section{References}

Bellak, C./Leibrecht, M./Damijan, J.P. (2009): Infrastructure endowment and corporate income taxes as determinants of Foreign Direct Investment in Central and Eastern European countries. The World Economy. 32, 2, 267-290.

Bellak, C./Leibrecht, M./Riedl, A. (2008): Labour costs and FDI flows into Central and Eastern European countries: a survey of the literature and empirical evidence. Structural Change and Economic Dynamics. 19, 17-37. 
Bevan, A.A./Estrin, S. (2004): The determinants of foreign direct investment into European transition economies. Journal of Comparative Economics. 32, 775-787.

Brewer, P. (2007): Operationalizing psychic distance: A revised approach. Journal of International Marketing. 15, 1, 44-66.

Brock, D.M./Shenkar, O./Shoham, A./Siscovick, I.C., (2008): National culture and expatriate deployment. Journal of International Business Studies. 39, 1-17.

Buch, C.M./Kokta, R.M./Piazolo, D. (2003): Does the East get what otherwise flows to the South? FDI diversion in Europe. Journal of Comparative Economics. 31, 1. 94-109.

Carr, S.C./Rugimbana, R.O./Walkom, E./Bolitho, F.H. (2001): Selecting expatriates in developing areas: Country of origin effects in Tanzania? International Journal of Intercultural Relations. 25, 441-457.

Cavusgil, S. T. (1980): On the internationalization process of firms. European Research. 8, November, 273-281.

Cho, K. R./Padmanabhan, P. (2005): Revisiting the Role of Cultural Distance in MNC's Foreign Ownership Mode Choice: The Moderating Effect of Experience Attributes. International Business Review. 14, 3, 307-324.

Cramer, J.S. (1991): The logit model: an introduction for economists. Edward Arnold, London.

Damijan, J.P./Majcen, B./Rojec, M./Knell, M. (2003): The role of FDI, R\&D accumulation and trade in transferring technology to transition countries: evidence from firm panel data for eight transition countries. Economic Systems. 27, 2, 189-204.

Disdier, A.C./Mayer, T. (2004): How different in Eastern Europe? Structure and determinants of location choice by French firms in Eastern and Western Europe. Journal of Comparative Economics. 32, 280-296.

Dow, D. (2011): Web-pages on the research of Prof. Douglas Dow. http://www.mbs.edu/home/dow/research/(accessed 03/16/2011)

Dow, D./Ferencikova, S. (2010): More than just national cultural distance: Testing new distance scales on FDI in Slovakia. International Business Review. 19, 1, 46-58.

Dow, D./Karunaratna, A. (2006): Developing a Multidimensional Instrument to Measure Psychic Distance Stimuli. Journal of International Business Studies. 37, 5, 575-577.

Dow, D./Larimo, J. (2009): Challenging the Conceptualization and Measurement of Distance and International Experience in Entry Mode Choice Research. Journal of International Marketing. 17, 2, 74-98.

Ellis, P. (2008): Does psychic distance moderate the market size-entry sequence relationship? Journal of International Business Studies. 39, 3, 351-369.

Elteto, A. (2010): Foreign direct investment in Central and East European countries and Spain: Ashort overview. ICEI working papers.

Evans, J./Mavondo, F.T. (2002): Psychic distance and organizational performance: An empirical examination of international retailing operations. Journal of International Business Studies. 33, 3, 515-532. 
Galan, J.I./González-Benito, J./Zúñiga-Vicente, J.A. (2007): Factors determining the location decision of Spanish MNE: an analysis based on the investment development path. Journal of International Business. 38. 975-997.

Galego, A./Vieira, C./Vieira, I. (2004): The CEECs as FDI attractors: are they a menace to the EU periphery? Emerging Markets Finance and Trade. 40, 5, 74-91.

Ghemawat, P. (2001): Distance still matters: The hard reality of global expansion. Harvard Business Review. 79, 18, 137-147.

Ghemawat, P. (2003): The forgotten strategy. Harvard Business Review. 81, 11, 76-87.

Gomez-Barroso, J.L./Feijoo, C. (2010): Are Central and Eastern European countries managing to develop the information society? Transformations in Business \&Economics. 9, 2(20), 18-41.

Griffith, D. A./Cavusgil, S. T./Xu, S. (2008): Emerging themes in international business research. Journal of International Business Studies. 39, 1220-1235.

Hair, J.F./Anderson, R.E./Tatham, R.L./Black, W. (1999): Análisis multivariante. Prentice Hall. $5^{\text {th }}$ Edition. Madrid.

Håkanson, L./Ambos, B. (2010): The antecedents of psychic distance. Journal of International Management. 16, 3, 195-210.

Hausman, J./McFadden, D. (1984): A Specification Test for the Multinomial Logit Model. Econometrica. 52, 1219-1240.

Henderson-Kassis, J. (2005): Language diversity in international management teams. International Studies of Organization \& Management, 35, 2, 66-82.

Hofstede, G. (1980): Cultural Consequences: International Differences in Work Related Values. Beverly Hills: Sage Publications.

Holland, D./Pain, N. (1998): The diffusion of innovations in Central and Eastern Europe: A study of the determinants and impact of foreign direct investment. NIESR Discussion Papers, 137. National Institute of Economic and Social Research.

Holland, D./Sass, M./Benacek, V./Gronicki, M. (2000): The determinants and impact of FDI in Central and Eastern Europe: a comparison of survey and econometric evidence. Transnational Corporations. 9, 3, 163-213.

Hosseini, H. (2008): Psychic distance, psychic distance paradox and behavioral economics: Modeling MNC entry behavior in foreign markets. Journal of Socio-Economics. 37, 3, 939-948.

Jiménez, A. (2010): Does political risk affect the scope of expansion abroad? Evidence from Spanish MNEs. International Business Review. 19, 6, 619-633.

Jiménez, A. (2011): Political risk as a determinant of Southern European FDI in neighbouring developing countries. Emerging Markets Finance and Trade. 47, 4, 59-74.

Jiménez, A./De la Fuente, J.M./Durán, J.J. (2011a): Is there an East-West structure in the location of FDI in Europe? The role of institutions and political risk. Research in Economics and Business: Central and Eastern Europe. 3, 1, 5-23.

Jiménez, A./Durán, J.J./De la Fuente, J.M. (2011b): Political risk as a determinant of investment by Spanish multinational firms in Europe. Applied Economic Letters. 18, 8, 789-793. 
Johanson, J./Vahlne, J.E. (1977). The Internationalization Process of the Firm-A Model of Knowledge Development and Increasing Foreign Commitments. Journal of International Business Studies. 8, 1, 23-32.

Johanson, J./Wiedersheim-Paul, F. (1975). The Internationalization of the Firm: Four Swedish Cases. Journal of Management Studies. 12, 305-322.

Kennedy, P.A. (1992): Guide to econometrics. MIT Press: Cambridge, MA.

Kirkman, B.L./Lowe, K.B./Gibson, C.B. (2006): A Quarter Century of Culture'sConsequences: A Review of Empirical Research Incorporating Hofstede's Cultural Values Framework. Journal of International Business Studies. 37, 3, 285-320.

Kogut, B./Singh, H. (1988): The Effect of National Culture on the Choice of Entry Mode. Journal of International Business Studies. 19, 3, 411-432.

Li, J./Rugman, A. (2007): Real options and the theory of foreign direct investment. International Business Review. 16, 6, 687-712.

Maddala, G.S. (1993): Limited-dependent and qualitative variables in econometrics. Cambridge Univ. Press, Cambridge.

Majocchi, A./Presutti, M. (2009): Industrial clusters, entrepreneurial culture and the social environment: The effects on FDI distribution. 18, 1, 76-88.

Mayer, T./Mucchielli, J.L. (1999): La localisation à l'étranger des entreprises multinationales. Économie et statistique. 326-327, 159-176.

McFadden, D.L. (1984): Econometric analysis of qualitative response models. In Grilicjes, Z. Intriligator, M.D. (Eds), Handbook of Econometrics, 2. Elsevier/North-Holland, Amsterdam, 1396-1457.

Nachum, L./Zaheer, S./Gross, S. (2008): Does it matter where countries are? Proximity to knowledge, markets and resources, and MNE location choices. Management Science. $54,7,1252-1265$.

Neter, J./Wasserman, W./Kutner, M.H. (1985): Applied linear statistical models: regression, analysis of variance and experimental designs. $2^{\text {nd }}$ Ed. Irwin, Homewood.

O' Grady, S./Lane, H.W. (1996): The psychic distance paradox. Journal of International Business Studies 27, 2, 309-333.

Ojala, A./Tyrvainen, P. (2009): Impact of psychic distance to the internationalization behavior of knowledge-intensive SMEs. European Business Review. 21, 3, pp.263-277.

Peng, M./Wang, Y. D./Jiang, Y. (2008): An institution-based view of international business strategy. Journal of International Business Studies. 39, 920-936.

Peneder, M./Stehrer, R. (2007): Neighbours in Transition. National Institute Economic Review. 200, 96-104.

Pennings, E./Altomonte, C. (2003): The hazard rate of foreign direct investment in transition countries: a direct estimation of a real option model. Working Paper presented at the CEPR Workshop: The economic Geography of Europe: Measurement, Testing and Policy Simulations:

Prime, N./Obadia, C./Vida, I. (2009): Psychic distance in exporter-importer relationships: A grounded theory approach. International Business Review. 18, 2, 184-198. 
Resmini, L. (2000): The determinants of foreign direct investment into the CEECs: new evidence from sectoral patterns. Economics of Transition. 8, 665-689.

Rivoli, P./Salorio, E. (1996): Foreign direct investment and investment under uncertainty. Journal of International Business Studies. 27, 2, 335- 357.

Shenkar, O. (2001). Cultural Distance Revisited: Towards a More Rigorous Conceptualization and Measurement of Cultural Differences. Journal of International Business Studies. 32, 3, 519-536.

Shenkar, O./Luo, Y./Yeheskel, O. (2008): "From "distance" to "friction": Substituting metaphors and redirecting inter-cultural research. Academy of Management Review. $33,4,905-923$.

Smarzynska, B.K. (2002): Composition of foreign direct investment and protection of intellectual property rights: Evidence from transition economies. Policy Research Working Paper No. 1786, World Bank, Washington.

Sousa, C.M.P./Bradley, F. (2006): Cultural distance and psychic distance: Two peas in a pod? Journal of International Marketing. 14, Iss. 1, 49-70.

Studenmund, A. H. (1992): Using econometrics: a practical guide. HarperCollins: New York.

Statacorp (2001): Stata statistical software: Release 7.0. College Station, Tx: Stata Corporation.

Tihanyi, L./Griffith, D. A./Russell, C. J. (2005). The Effect of Cultural Distance on Entry Mode Choice, International Diversification, and MNE Performance: A Meta-Analysis. Journal of International Business Studies. 36, 3, 270-283.

Triandis, H.C. (2000): Culture and conflict. International Journal of Psychology. 35, 2, 145152.

Tung, R.L./Verbeke, A. (2010): Beyong Hofstede and GLOBE: Improving the quality of cross-cultural research. Journal of International Business Studies. 41, 1259-1274.

Yamin, Y./Sinkovis, R.R. (2006): Online internationalisation, psychic distance reduction and the virtuality trap. International Business Review. 15, 4, 339-360.

Welch, D.E./Welch, L.S./Marschan-Piekkari, R. (2001): The persistent impact of language on global operations. Prometheus. 19, 3, 193-209.

Williamson, O.E. (1975): Markets and Hierarchies: Analysis and antitrust implications. New York: Free Press.

Williamson, O.E. (1985): The economic institutions of capitalism. New York: Free Press.

www.mityc.es Spanish Ministry of Industry, Energy and Tourism website (accessed 03/29/2011)

www.unctad.org United Nations Conference on Trade and Development website (accessed 03/17/2011)

Zaheer, S./Schomaker, M.S./Nachum, L. (2012): Distance without direction: Restoring credibility to a much-loved construct. Journal of International Business Studies. 43, $18-27$. 